\title{
Legal Protection for Registered Mark Owners Through the Application of Criminal Mark Law
}

\author{
Subianto \\ \{ssubianto@yahoo.com\} \\ Doctor of Law, Universitas Jayabaya, Jakarta, Indonesia
}

\begin{abstract}
Legal protection against trademark piracy has become a concern today. Counterfeiting of a mark or unauthorized use of a mark against a well-known mark does not only constitute a criminal offense. Through the application of the criminal law on Marks which can affect legal protection for registered mark owners and how the Trademark Law regulates alternative sanctions to become cumulative, violations of the law become criminal acts. The method used in this research is descriptive legal research analysis which is carried out in an effort to obtain the necessary data in connection with the problem. The data used are secondary data consisting of primary legal materials, secondary legal materials, and tertiary legal materials. The results of the study conclude that criminal sanctions in the form of imprisonment or fines are imposed on the perpetrators of criminal acts in the field of marks who violate the provisions of Article 94 of Law no. 21 of 2001 which may affect legal protection for registered mark owners. The application and understanding of Article 91 of Law Number 15 Year 2001 concerning Marks, namely the use of a mark without rights which is essentially the same as a registered trademark owned by another person, is in accordance with the decision of either the District Court, High Court, Supreme Court Cassation to with different Supreme Court Reviews because of different perceptions and understandings of each. There needs to be a change in one of the clauses that originally stipulated alternative sanctions to be cumulative, namely by eliminating the word or the threat of punishment and initially breaking the law into a criminal act. Regarding the protection and application of the law on trademarks, by changing the complaint offense clause in the crime of Mark into a common crime.
\end{abstract}

Keywords: Legal Protection, Trademark, Crime

\section{Introduction}

Counterfeiting of a mark or the unauthorized use of a mark against a well-known mark does not only constitute a criminal offense, apart from qualifying as a criminal act of counterfeiting, it can also be classified as intellectual property theft. In various countries, standard laws have been established in the legislation which confirms that falsification of marks is a criminal offense [1]. The average firm, which experiences direct competition with counterfeiters, suffers an immediate loss in sales. Some markets are dominated by counterfeiters, creating barriers for genuine goods makers to enter the market. Furthermore, consumers are deceived into buying counterfeit goods that are thought to be genuine products, when they realize that they blame the original brand owner for the low quality of the goods which are in fact fake, this causes the loss of good name or reputation of the company concerned.

Before Law No. 15 of 2001 concerning Trademarks (State Gazette of the Republic of Indonesia of 2001 Number 110) which was ratified on August 1, 2001, Supplement to the State 
Gazette of the Republic of Indonesia Number 4131, previously applied Law No. 19 of 1992 which has been amended into Law no. 14 of 1997, the provisions concerning Marks regulated in Law No. 21 of 1961 concerning Company and Commercial Marks, in which no criminal sanctions are found for the perpetrators so that the criminal provisions contained in the Criminal Code and other related criminal provisions are used against the perpetrators.

Violations of registered marks can be resolved through several channels, Law Number 15 the Year 2001 concerning Marks in article 95 states that the criminal acts referred to in article 90, article 91, article 92, article 93, and article 94 constitute an offense in the complaint. The trademark registration system in Indonesia uses a constitutive system (registration), not a declarative system (first user) [2]. Considering that a trademark is part of the economic activity/business world, the resolution of Mark disputes requires a special judicial body, namely the Commercial Court, a special procedural law must be regulated to resolve Mark disputes as well as other areas of intellectual property rights.

From the aforementioned matters, the parties are given the choice of which route is more appropriate, whether through a lawsuit in the Commercial Court, arbitration, or criminal law. If the owner of a mark that is legally registered in the General Register of Marks, if there is a violation of the use of the mark without rights and other efforts cannot be resolved, then the final alternative is to take the criminal route by reporting to the National Police Investigator or to certain Civil Servant Investigators (PPNS) at Directorate General of Intellectual Property Rights of the Ministry of Law and Human Rights of the Republic of Indonesia.

This criminal route was pursued because other channels did not produce results or because the aggrieved party wanted to provide learning to brand users without rights (brand counterfeiters). Examples of cases of criminal offenses in the field of trademarks in Indonesia that are quite prominent, namely [3]:

1. The case for the "BOS KOPI" brand and its packaging which has substantial similarities to the "KOPIKO" brand and its packaging for the type of confectionery goods that occur in Jakarta.

2. Unauthorized use of the trademark "Channel" mark for goods in the form of wallets and bags bearing the Channel logo, which occurred between 1995-1996 in Denpasar.

3. The case of the brand "Holland Bakery" for the type of goods/services of product class 30, namely food, bread, and pastries that use the words "Holland Bakery" and a picture of a windmill that occurs in Yogyakarta.

There are several similarities in the application of trademark law in Indonesia and in the United States. Based on the aforementioned background, the problem in this writing that is being studied is whether article 91 of the Trademark Law concerning equality, in essence, needs to be clarified, so that registered trademark owners get more legal protection than through the application of the criminal law on Mark can it affect legal protection for the owner of a registered mark and should the Trademark Law stipulate that alternative sanctions become cumulative, violation of the law becomes a criminal act.

\section{Research Methods}

This type of research uses normative juridical research methods and comparative law methods, namely research that refers to legal norms contained in statutory regulations, international conventions, international treaties, and court decisions. which is descriptive- 
analytic, which is a study that aims to provide a clear, systematic, real, and precise description and description of the application of the criminal law on a trademark against registered mark owners.

\section{Results and Discussion}

Intellectual Property Rights are the equivalent of Intellectual Property Rights which is defined as the protection of works that arise due to human intellectual abilities in the fields of art, literature, science, aesthetics, and technology. In the field implementation in handling criminal acts of trademarks or civil lawsuits, there is often the use of a mark which is similar to a registered mark, whether the mark is registered in the General Register of Marks or not registered but cannot be categorized as a criminal offense on a mark. In order to protect registered mark owners, especially those involving criminal acts, it is necessary to add to the application of criminal acts in addition to equality in their entirety, equality in essence needs to be applied to articles relating to fraudulent competition and before any amendments to the Trademark Law it is necessary to apply article 382 bis KUHP.

However, from many criminal incidents, there are several types, almost all crimes that can only be prosecuted on a complaint (request) from a person who is subject to a criminal event, while complaints against unknown violations, criminal events of this kind are usually called complaint offenses. The reason for the complaint offense is that in some cases it is more advantageous for the person concerned not to prosecute the case than it is to the government (society) that prosecution is carried out. The existence of this complaint offense does not reduce the opportunities principle in the criminal prosecution law, that the public prosecutor (prosecutor) always (including for complaint offenses) has the power to save (call) the case for the public interest.

As Article 90 of Law no. 15 of 2001 concerning Mark states Anyone who deliberately and without rights uses the same Mark in its entirety with the registered Mark of another party for similar goods and/or services produced and/or traded, shall be punished with imprisonment of 5 (five) years. and/or a maximum fine of Rp. 1,000,000,000.00 (one billion rupiah). Article 91 of the Trademark Law states Anyone who deliberately and without rights uses the same Mark in essence as a registered mark owned by another party for similar goods and/or services produced and/or traded, shall be punished with imprisonment of 4 (four) years. and/or a maximum fine of Rp. 800,000,000.00 (eight hundred million rupiah).

Judging from the criminal threat from Article 90, Article 91, Article 92, Article 93, and Article 94 of Law Number 15 the Year 2001 states that there is a sentence being sentenced and/or a fine or fine so that the defendant can be subject to criminal or fine, this will be the effect is not detained for the perpetrator of the criminal act, because on average the perpetrator of a criminal act is someone who has more money so they can choose a fine as an alternative. To further protect registered mark owners and to make the perpetrators more deterred, the sanctions should be cumulative, namely imposing and imposing imprisonment plus a fine.

Likewise, Article 94 paragraph (2) of the Trademark Law states that the criminal act referred to in paragraph (1) is a violation. Thus, the Trademark Law regulates the existence of criminal acts and violations, in order to protect registered mark owners, and for a more deterrent effect, violations may be eliminated, or all replaced as criminal acts. As referred to in Article 95 of Law No. 15 of 2001 concerning Marks states that the criminal offense as referred to in Article 90, Article 91, Article 92, Article 93, and Article 94 constitutes a complaint offense. This can 
create problems because if the trademark owner does not make a complaint, it means that there will be no criminal offense in the field of Mark. Apart from that, the opportunity for the victim (the public) to be able to file a complaint or report that there has been a crime in the field of Mark is not regulated and the crime of mark is an absolute complaint offense, even though in Law No. 8 of 1999 concerning Consumer Protection has regulated it. The absence of such complaints causes the perpetrators of criminal offenses in the field of Mark to escape criminal responsibility, which in the end, the perpetrators of criminal offenses in the field of Mark cannot be convicted.

Civil liability does not cover criminal liability, on the other hand, criminal liability can be used as a basis for strengthening civil litigation. The occurrence of peace in civil cases for violation of marks does not preclude criminal liability [4]. Likewise, there are weaknesses, namely if the criminal case of the mark has been followed up by the investigator by means of an investigation, but on the way the reporter withdraws the complaint then the case must be stopped. This has resulted in frequent cases of extortion by registered mark owners as reporters against trademark users without rights (reported) to hand over a number of funds as compensation. Investigations that have been carried out by investigators are futile, even though the public and the state are often harmed by the use of marks without rights or falsification of these marks.

With the weaknesses contained in Law no. 15 of 2001 concerning the Mark, it is necessary to Law No. 15 of 2001 was amended, in particular the provisions of Article 95, namely being changed into a common crime. This means that in order to demand criminal responsibility from the perpetrators of criminal acts in the field of marks, there is no need to wait for the registered mark owner to make a complaint. This is due to the fact that victims of criminal acts in the field of marks other than registered mark owners or registered trademark licensees also concern society, the credibility or dignity of the nation and state of the Republic of Indonesia, both in their own country, including taxes and in the international community [5].

For this reason, the form of a criminal offense in the field of Marks should be in the form of a normal crime and not a complaint. It is also necessary to regulate provisions regarding sanctions that can be imposed on corporations as perpetrators of criminal offenses in the field of Marks, in addition to setting sanctions on the management or owners of the corporation itself. In accordance with the inherent characteristics of the corporation, the criminal sanctions that can be threatened against the corporation are the principal fines and also need to regulate additional criminal threats in the form of announcements of judicial decisions and revocation of business licenses.

Law enforcement is called in English Law enforcement, Dutch language Rechtshandhaving. The term law enforcement in Indonesian leads to the idea that law enforcement is always by force, so there are those who argue that law enforcement is only concerned with criminal law. This kind of thinking is reinforced by the habit of calling law enforcers police, prosecutors, and judges not called administrative officials who actually enforce the law. If the term law enforcement was copied into legal handling, it would be more in accordance with this context, where law enforcement has a broader scope.

In law enforcement, it is necessary to have control (controle), which means that government supervision is required to comply with the provision of regulations that are parallel to investigations in criminal law. Prior to the implementation of law enforcement, negotiations, persuasion, and supervision were often held so that legal regulations or permit conditions were obeyed, this is usually called compliance. Americans and Canadians distinguish between the meaning of law enforcement, which means repressive law enforcement, while compliance means preventing violations of the law, while the Dutch, both phases are handhaving. 
Before repressive actions are taken, preventive measures are taken including information and advice. In the enforcement of trademark law in Indonesia which regulates intellectual property objects, Trade-Related Aspects of Intellectual Property (TRIPs) also contains national law enforcement with the aim of preventing and overcoming violations in the field of intellectual property rights in a country. The regulation and meaning of law enforcement have been explained and mentioned above, while law enforcement in intellectual property contains an outline of the powers (rights) given to judicial bodies, administrative bodies (customs), and holders of intellectual property rights themselves, in the event of a violation involving the use of Intellectual property rights. The level of mastery/understanding of the material is still minimal among law enforcement officials, namely investigators, public prosecutors, and judges in charge of IPR, especially Marks and the limited number and quality of Investigators, Public Prosecutors, and Judges who truly master the material of IPR legislation, including Marks professionally.

To obtain legal certainty in investigations, prosecution and judiciary can place the violation of a mark in its true proportion based on the provisions contained in the Trademark Law purely and consequently, as well as a preventive effort to prevent the community using marks from falsifying other people's brands.

\section{Conclusion}

The results of the study concluded that the legal protection of trademarks is needed in order to ensure that registered trademarks are not copied, hijacked, and hijacked by irresponsible parties. Criminal sanctions arrangements based on Law no. 21 of 2001 concerning Marks, because criminal offenses in the field of marks can cause considerable material losses. On the other hand, by registering and announcing a registered mark in the General Register of Marks, the problem of marks has entered the area of public law, so that the existence of criminal sanctions is a form of protection to the public. Criminal sanctions in the form of imprisonment or fines are imposed on the perpetrators of criminal acts in the field of marks who violate the provisions of Article 94 of Law no. 21 of 2001 which may affect legal protection for registered mark owners. The application and understanding of Article 91 of Law Number 15 Year 2001 concerning Marks, namely the use of a mark without rights which is essentially the same as a registered trademark owned by another person, is in accordance with the decision of either the District Court, High Court, Supreme Court Cassation to with different Supreme Court Reviews because of different perceptions and understandings of each.

Even though the explanation of the equations is basically clear, the understanding of law enforcers does not fully understand it completely, so that in the application of both the levels of investigation, prosecution and trial are out of sync. It is necessary to include a detailed explanation of the notion of equality in essence, so that there is no misinterpretation in its implementation that can protect registered mark owners, both in legal protection and in investment protection. There needs to be a change in one of the clauses that originally stipulated alternative sanctions to be cumulative, namely by eliminating the word or the threat of punishment and initially breaking the law into a criminal act. Regarding the protection and application of the law on trademarks, by changing the complaint offense clause in the crime of Mark into a common crime. 


\section{References}

[1] C.F.G. Sunaryati Hartono, Penelitian Hukum di Indonesia Pada Akhir Abad ke-20, (Bandung : Alumni, 1994)

[2] Cita Citrawinda Priapantja dalam makalah pada "Seminar HaKI dan Penegakan Hukumnya" yang diselenggarakan oleh Kedutaan Besar Perancis di Jakarta bekerjasama dengan Perhimpunan Masyarakat HaKI Indonesia pada tanggal 19-20 Juni 2003, di Hotel Sofitel Grand Mahakam, Jakarta,

[3] Cita Citrawinda, Sekilas tentang Tindak Pidana dalam Bidang Merek, (Jakarta : Jurnal_ Legislasi, Okt 2006),

[4] Jawaban Pemerintah atas Pemandangan Umum Fraksi-fraksi DPR-RI terhadap Rancangan Undangundang tentang Merek, tanggal 17 Pebruari 1992.

[5] O.C. Kaligis, Pendapat Ahli Dalam Perkara Pidana, (Bandung : PT. Alumni, 2008)

[6] R. Soesilo, Kitab Undang-undang Hukum Pidana (KUHP) serta Komentar-komentarnya lengkap pasal demi pasal, (Bogor : Politeia, 1980),

[7] Tim Lindsey dkk, Hak Kekayaan Intelektual Suatu Pengantar, (Jakarta : PT. Alumni, 2002),

[8] Undang-undang Nomor 15 tahun 2001 tentang Merek.

[9] Email : library@lib.unair.ac.id:library@unair.ac.id 